\title{
Cloning and expression of pab gene of M. tuberculosis isolated from pulmonary TB patient in E.coli DH5 $\alpha$
}

\author{
Tri Yudani M. Raras, ${ }^{1}$ Diana Lyrawati ${ }^{2}$ \\ ${ }^{1}$ Department of Biochemistry-Molecular Biology, Universitas Brawijaya, Malang, Indonesia \\ ${ }^{2}$ Department of Pharmacy, Faculty of Medicine, Universitas Brawijaya, Malang, Indonesia
}

\begin{abstract}
Abstrak
Latar belakang: Antigen38 Mycobacterium tuberculosis merupakan agen serodiagnostikyang potensial karena mengandung dua epitop spesifik untuk sel B. Mahalnya agen diagnostik menyebabkan lambatnya realisasi diagnosis TB secara cepat di negara berkembang. Kami memproduksi antigen 38 rekombinan yang berasal dari galur lokal yang kemungkinan dapat digunakan untuk memproduksi alat serodiagnostik TB yang ekonomis.

Metode: Gen pab diisolasi dari pasien TB paru di Malang, diklon ke plasmid pGEM-Teasy menjadi pMB38. Klon E.coli DH5a yang membawa pMB38 diseleksi di medium yang ditambah dengan X-Gal. Ekspresi pab dilakukan menggunakan pMBhis yang berasal dari pPRoExHTc dibawah kontrol promoter Trc dengan inang E.coli DH5a

Hasil: Pencocokan sekuen gen pab dari klon E.coli DH5a berwarna putih dengan gen pab dari M. tuberculosisH37Rv memperlihatkan homologi sebesar 98\%. Protein rekombinan yang sudah dihilangkan signal peptidanya ditemukan di sitoplasma.
\end{abstract}

Kesimpulan: Gen pab dari pasien TB dapat diekspresikan secara intraseluler dengan sistem heterolog. (Med J Indones 2011; 20:247-55)

\begin{abstract}
Background: Mycobacterium tuberculosis antigen38 is a potent serodiagnostic agent containing two M. tuberculosisspecific B-cell epitopes. The high price of imported diagnostic agents hinders realization of fast clinical TB diagnosis in developing countries. Therefore, we produced recombinant antigen 38 (recAg38M) from M. tuberculosis local strain, which might be used to produce economical tuberculosis serodiagnostic kit.

Methods: $P a b$ gene that was isolated from pulmonary TB patient in Malang was cloned into a plasmid vector (pGEMTeasy) to construct pMB38. The E.coli DH5 $\alpha$ clone carrying pMb38 was selected on X-gal medium. The expression of pab was mediated using pPRoExHTc under the control of Trc promoter and E.coli DH5 $\alpha$ as host.

Results: Alignment of the pab sequence from the white E.coli DH5 $\alpha$ clones with that of M. tuberculosis H37Rv showed $98 \%$ homology. The recombinant protein in which the signal peptide has been deleted to prevent the protein being secreted into medium was found in the cytoplasm.
\end{abstract}

Conclusion: $p a b$ gene of $M$. tuberculosis isolated from a TB patient could be expressed in heterologous system in $E$. coliDH5a. (Med J Indones 2011; 20:247-54)

Key words: Mycobacterium tuberculosis, Pab gene expression, recombinant antigen 38

Mycobacterium tuberculosis (M. tuberculosis) Antigen38, a phosphate-binding protein, has a function that is similar to periplasmic phosphate-binding protein of Escherichia coli (E.coli) i.e. as an initial receptor for active transport. ${ }^{1}$ Among other antigens that were used as tuberculosis serodiganostic agents, Antigen38, that contains two M. tuberculosis-specific B-cell epitopes has been shown as the most potent immunogen due to its high specificity and sensitivity. ${ }^{2}$ The high price of imported diagnostic agent hinders realization of fast clinical TB diagnosis in developing countries. One of the urgent goals of mycobacterial research in developing countries is to provide serodiagnostic agents. For such purpose, antigen need to be produced in a large scale. However, mass production of mycobacterial antigen using conventional system encountered several problems such as high cost laboratory facility, difficulty in the protein identification and reduction of immunogenicity after purification. ${ }^{3}$ An alternative solution to these problems would be the production of recombinant antigen in E.coli.

Therefore, in this study we aim to express the recombinant Antigen38 from $M$. tuberculosis local strain (recAg38M), in E.coli DH5a, which might be used to produce economical tuberculosis serodiagnostic kit.

\section{METHODS}

The antigen38 coding $p a b$ gene was amplified from M. tuberculosis that was isolated from the sputum of pulmonary TB patient. The pab gene containing overexpression plasmid was constructed by inserting the amplified fragment into the corresponding vector. In order to avoid a loss of protein in the medium during purification process, the putative signal peptide of 
the $p a b$ gene was omitted using specific primer design during the amplification of the gene and construction of the expression vector, enabling the protein to be expressed in the cytoplasm of $E$. coli rather than secreted into medium.

\section{Strain and plasmid}

The M. tuberculosis which gene was used in this work was isolated from a patient who was suffering from pulmonary tuberculosis and hospitalized in Batu public hospital, Malang. Written consent was obtained from the patient. The study was approved by the Ethics Committee of Saiful Anwar Public Hospital. Plasmid pGEM-Teasy was purchased from Promega (USA). Plasmid pPRoExHTc was kindly given by Dr Rintis Noviyanti from Eijkman Institute.

\section{Isolation and amplification of pab gene from chromosomal DNA of M. tuberculosis}

Bacterial DNA was isolated according to van der Zanden. ${ }^{4}$ The $p a b$ gene was amplified using PCR with modification, i.e. without putative signal sequence (amino acid position 1-23) and Cys1 was replaced with Met residue, and was amplified directly from the chromosomal DNA of $M$ tuberculosis using two oligonucleotides, as forward (sense) and reverse (antisense) primers (figure 1). ${ }^{5}$

Primer 1: pabF224 (5'-GGCGGCCATGGGCTC GAA ACCACCGAGCGG-3') carried an NcoI cleavage site and attached to a position 63 to 93 starting from initiation codon (ATG).

Primer 2: pab1342 3' (5'-CCAGCAGGATCC GCA AAGCAGCCCGATGGC-3') was located downstream from stop codon. It carries restriction site $\mathrm{BamH1}$ and correspond to the sequence at the position +1.002 to +974 counted from initiation codon ATG.

\section{Construction of plasmid pMB38}

The pab gene was amplified using PCR without the putative signal sequence. The amplified $p a b$ gene was cloned into pGEM-Teasy vector (Promega, USA) according to a standard method. ${ }^{6}$ The bacterial host for cloning and expression was E.coli DH5a (F-recAI endAI gyrA96 thi-1 hsdr17(rk-mk-) sup44 relAll(Ф80lacZDM15) $\Delta$ (lacZYA-arg F) U169). To maintain compatibility of the alignment with Antigen38, the deduced amino acid of the recombinant protein was renumbered so that Cystein that was replaced by Met became the first residue. The new construct was then named pMB38. (Figure 1).

\section{Screening of E.coli DH5 $\alpha / \mathrm{pMB} 38$}

Plasmid pMB38 was then used to transform E.coli DH5a using heat shock method, ${ }^{6}$ and the E.coli was spread on LB (Luria broth) solid medium supplemented with IPTG and X-gal. ${ }^{7}$ The white clones were selected and recultured in liquid medium. The presence of the pab gene was confirmed using PCR followed by sequencing.

\section{Construction of pMBhis}

Plasmid pMB38 was digested with NcoI, then electrophoresed on $12.5 \%$ agarose gel, and generated three fragments. The $1130 \mathrm{bps}$ fragment that corresponded to $p a b$ gene was then purified using Qiagen kit (USA) and ligated with pPRoExHTc vector that previously was linearised using the same restriction enzyme, and both DNA segments were then ligated to produce pMBhis (Figure 2). The ligation product was used to transform E.coli $\mathrm{DH} 5 \alpha$. Selection of E.coli DH5 $\alpha /$ pMBhis was conducted on ampicillin $100 \mathrm{mg} / \mathrm{mL}$ containing LB. The correct clone was confirmed via PCR.

\section{Expression of recAg38M in E.coli DH5a/pMBhis}

E.coli DH5 $\alpha /$ pMBhis was cultivated at $37^{\circ} \mathrm{C}$ in Ampicillin $(100 \mathrm{mg} / \mathrm{ml})$ containing LB medium to an OD600 of 0.6. The expression of pab was induced by addition of $0.6 \mathrm{mM}$ isopropyl-B-Dthiogalactopyranoside (IPTG). After 3 hours cells were harvested by centrifugation at $6000 \mathrm{xg}$ for $15 \mathrm{~min}$. The pellet was resuspended in 2.5 volume of $50 \mathrm{mM}$ potassium phosphate buffer ( $\mathrm{pH}$ 6.9) that contained 1 $\mathrm{mM}$ protease inhibitor, i.e. phenyl methyl sulphonyl fluoride (PMSF), and the cells were broken using a sonicator at $40 \%$ for 20 seconds, 3 times. The cell extract was then centrifuged for 15 minutes at $8.000 \mathrm{x} \mathrm{g}$. The supernatant was removed and further centrifuged (Bench Top Ultracentrifuge) at $30.000 \mathrm{xg}$ for 30 minutes to separate the S30 extract. The S30 extract was taken and underwent another centrifugation at $100.000 \mathrm{xg}$ for 90 minutes, and the supernatant was called S100, while the pellet was called P100. All cell fractions were subjected to $12.5 \%$ SDS-PAGE.

\section{Purification of recAg38M using batch system}

In this study the protein recAg38M was fused with $6 \mathrm{x}$ histidin tag that was located on $\mathrm{N}$ terminus site. Partial purification was performed in Eppendorf-cup according to the procedure from the manufacturer (Qiagen Ltd, Sweden). $250 \mathrm{ml}$ of nickel-Nitriloacetic acid agarose in Phosphate buffer ( $\mathrm{pH}$ 6.9) was incubated with $1 \mathrm{ml}$ of $\mathrm{S} 30$ extract of E.coli $\mathrm{DH} 5 \alpha / \mathrm{pMBhis}$ at $4^{\circ} \mathrm{C}$ for 1 hour with gently shaking. After that, the mixture was loaded into a tube filter and centrifuged for $1 \mathrm{~min}$. The tube was washed twice with Phosphate buffer containing 10 $\mathrm{mM}$ imidazol. In order to elute the protein that bound to Nickel, Phosphat buffer containing $250 \mathrm{mM}$ imidazole was applied. Protein elution was repeated 4 times. Finally all fractions were analysed using SDS-PAGE $10 \%$. The presence of protein 38 was confirmed using Commassie blue serva. 


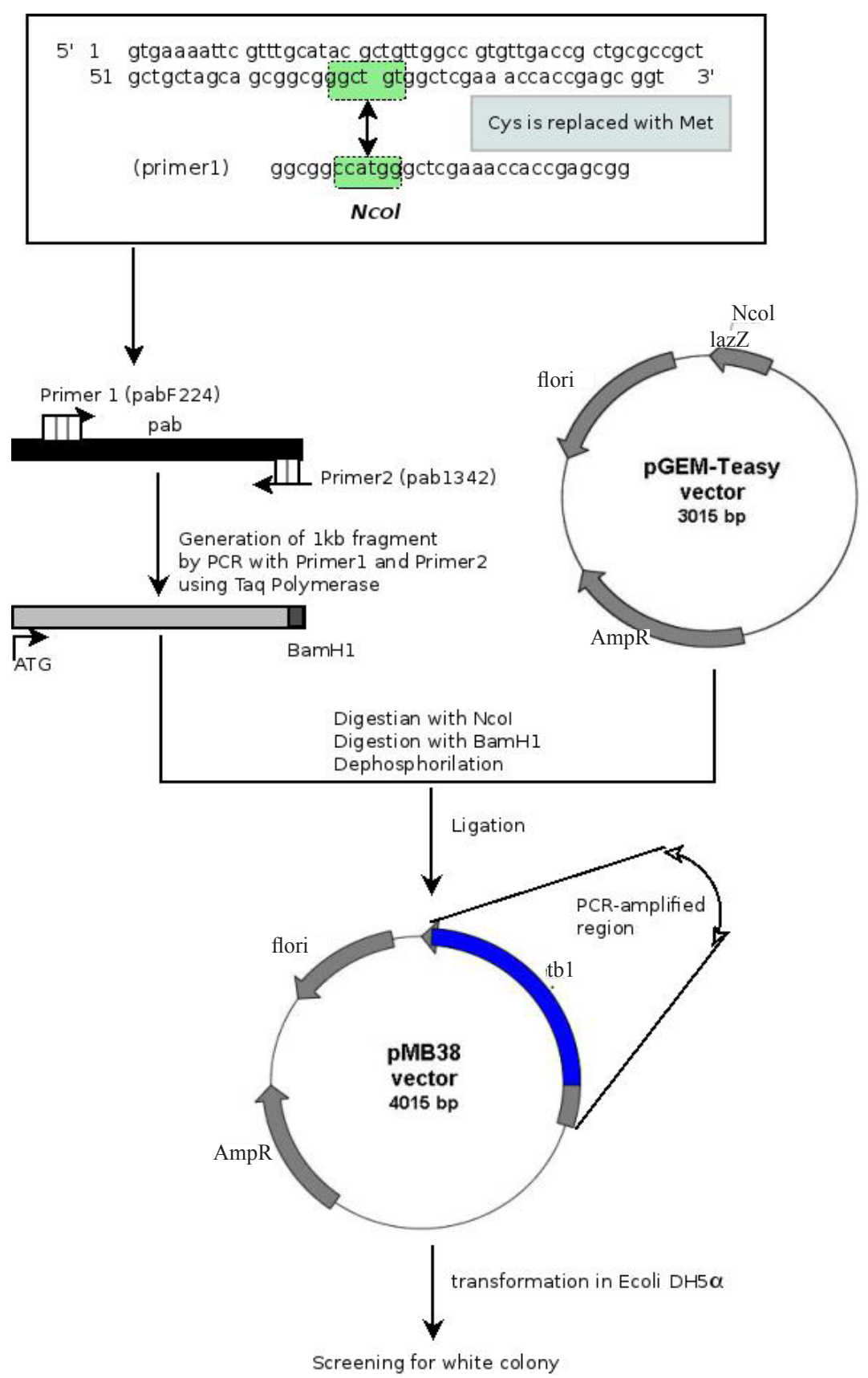

Figure 1. Construction of plasmid pMB38 (derivate of pGEM-Teasy). Plasmid pGEM-Teasy was digested with NcoI and ligated with PCR amplified product that was digested previously with NcoI and BamHI. The 3'overhang of insert (product of BamHI digestion) should ligate with 5' overhang of the plasmid (product of NcoI digestion) because there were only two different nucleotides within the cleavage site.

\section{Growth of E.coli DH5a/pMB38}

To examine whether the expression of pMB38 influence the growth of the host, growth tests were performed.

\section{RESULTS}

\section{Construction of pMB38 and pMBhis}

Primers were designed to modify $p a b$ gene by omitting the putative signal peptide. As a result, a band corresponded to $950 \mathrm{bp}$ appeared after DNA amplification (Figure 3 ). This segment $(t b 1)$ was slightly shorter than that of the pab gene from M. tuberculosis $37 \operatorname{Rv}(1260 \mathrm{bp})$. The segment $t b 1$ was then inserted into pGEM-Teasy to produce pMB38. Transformation of $E$. coli with pMB38 generated numerous white clones on plates containing X-Gal. We tested 12 clones and all carried the insert. Sequence analysis of $t b 1$ showed a $98 \%$ homology to the sequence of $p a b$ gene of the $M$. tuberculosis $\mathrm{R} 37 \mathrm{v}$ that was retrieved from published sequence in Gene Bank NCBI (Figure 4). 


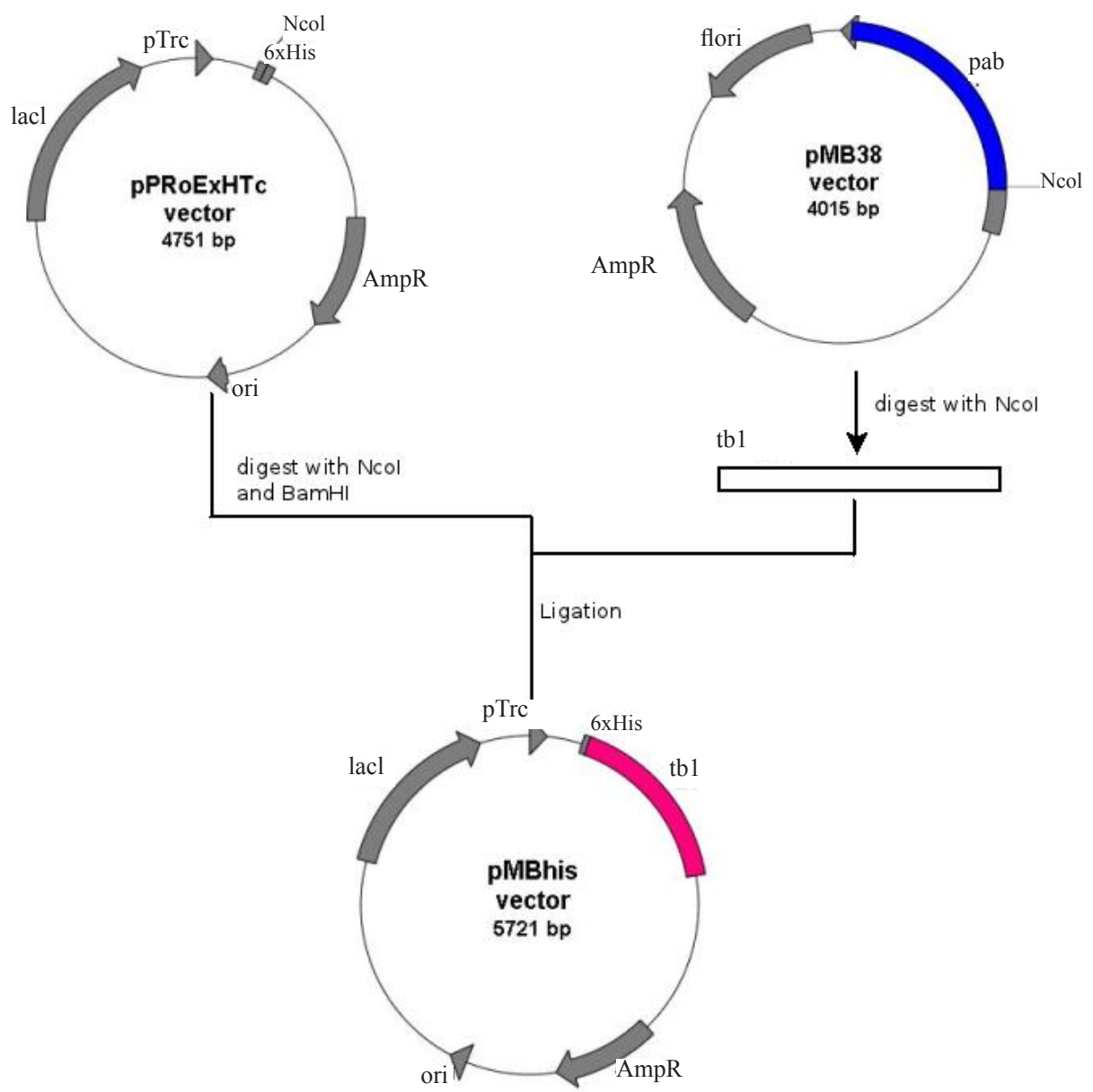

Figure 2. Construction of plasmid pMBhis (derivate of pPRoEXHTc). Plasmid pMB38 was digested with NcoI producing insert (tb1) while pPRoExHTc was double digested with NcoI and BamHI. The fragment tbl was then ligated into pPRoExHTc. To ensure that the insert (tb1) bound to the plasmid in the correct direction, restriction test was perfomed.

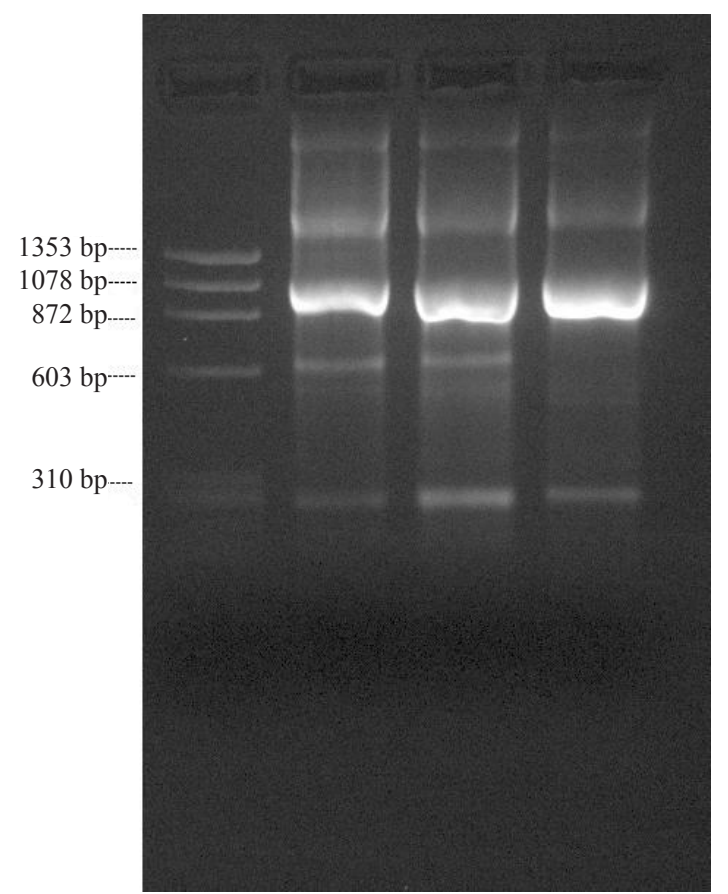

Figure 3. Amplified pab fragment from chromosomal DNA of M. tuberculosis. Lanes: 1= DNA marker, 2-4= amplified pab gene correspond to $970 \mathrm{bp}$. 


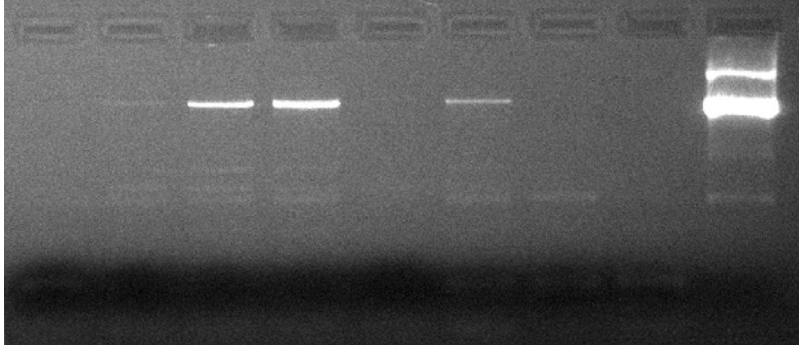

$\begin{array}{lllllllll}1 & 2 & 3 & 4 & 5 & 6 & 7 & 8 & 9\end{array}$

Figure 5. PCR-results of the amplification of pab gene on several clones of E.coliDH5a/pMBhis

Lanes: 1= Negative control, 2-8=Colonies 1-7, 9=tb1 Lane 3,4 and ,6 were positive showing the presence of fragment tb1.

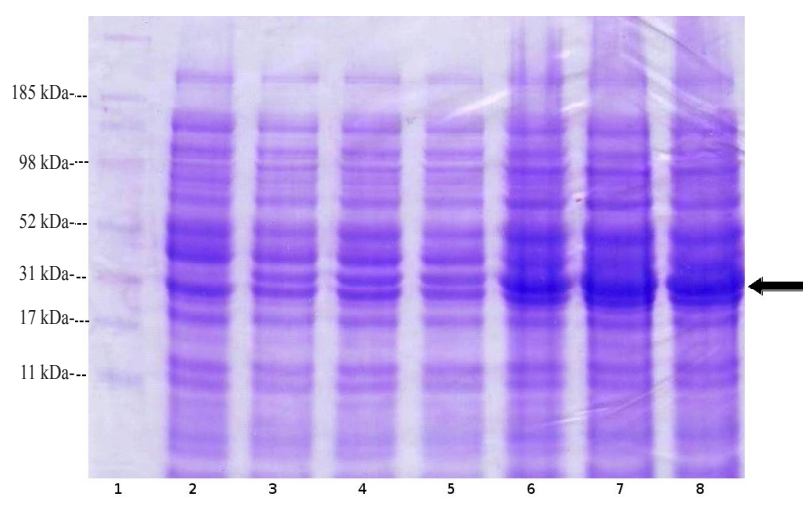

Figure 6. SDS-PAGE of extracts from cells that expressed the Ag38-His fusion protein

Lanes: $1=$ molecular mass standard, $2=$ cell extract of E.coliDH5a/pMBhis before induction, 3, 6= land 2 hours after induction with 200mM IPTG, 4, 7=1 and 2hours after induction with $400 \mathrm{mM} \mathrm{IPTG}, 5,8=1$ and 2 hours after induction with $600 \mathrm{mM} I P T G$.

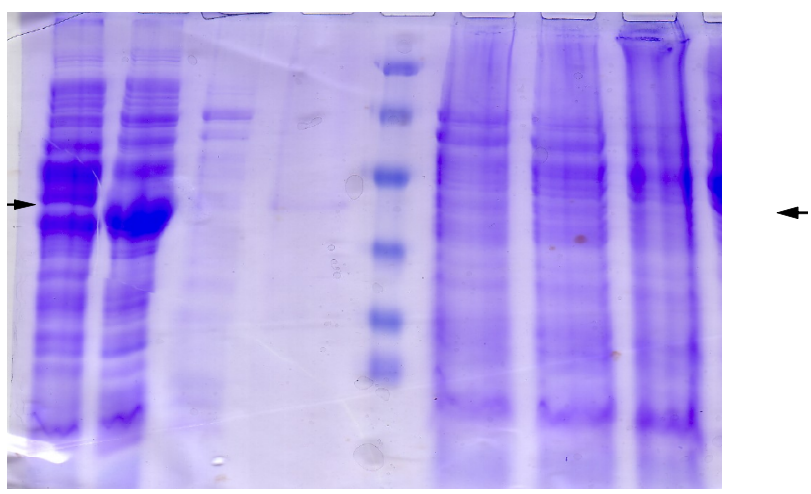

$\begin{array}{lllllllll}1 & 2 & 3 & 4 & 5 & 6 & 7 & 8 & 9\end{array}$

Figure 7. SDS-PAGE of extract of cells producing the Ag38M fusion protein

Lanes: $1=$ cell extract of E.coliDH5 $\alpha$ pMBhis without IPTG induction, $2=$ after IPTG induction, $3=$ the 8,000 $\times g$ supernatant, $4=$ the $8,000 \times$ g precipitate, $5=$ Molecular mass standard (from top to bottom): galactosidase $(118 \mathrm{kD})$, bovine serum albumin $(90$ $\mathrm{kD}$ ), ovalbumin $(50 \mathrm{kD})$, carbonic anhydrase $(34 \mathrm{kD})$, b-lactoglobulin $(26 \mathrm{kD})$, lysozyme $(19 \mathrm{kD}), 6=$ the 30,000 $x \mathrm{~g}$ supernatant (S30), $7=$ the 30,000 $\times$ g precipitate (P30), 8= the 100,000 $\times \mathrm{g}$ supernatant (S100), 9= the 100,000 $x$ g precipitate (P100)

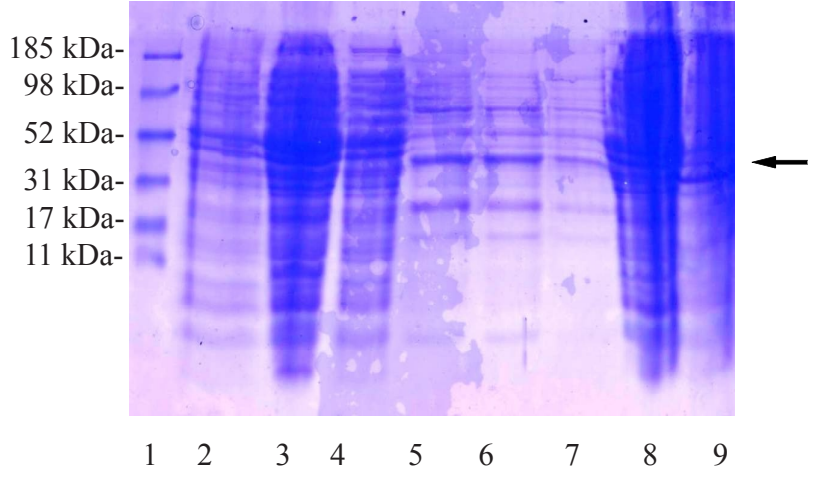

Figure 8. Purification of protein rec-Ag38M

S30 was mixed with matrix Ni-NTA, shaked gently for 1 hour and apllied onto filter.

Lanes : 1= Protein marker, $2=$ Flow through $(F L), 3=$ Wash $I$ (W1), 4= wash II (W2),5=Elution I (E1), 6= Elution II (EII),

$7=$ Elution III (EIII), $8=S 30,9=P 30$.

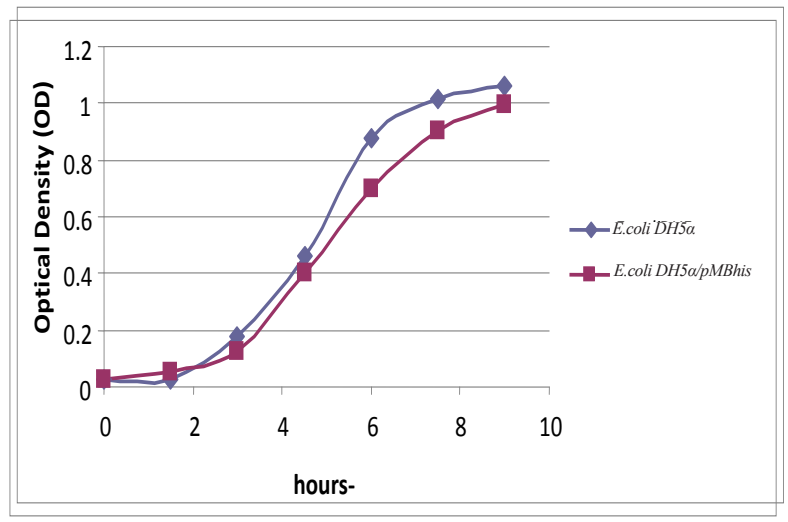

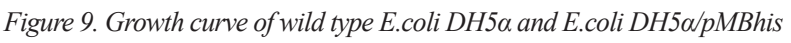

For the expression of $t b 1$, plasmid pMBhis was used and E.coli DH5 $\alpha$ served as the host. Transformation of E.coli/ pMBhis resulted in several white clones only. Seven white colonies were picked and confirmation with PCR showed that four colonies carried the $t b 1$ gene (Figure 5).

\section{Expression of pab gene of M. tuberculosis in E.coli}

In this study pab gene could be successfully expressed in E.coli $\mathrm{DH} 5 \alpha$. For this purpose E.coli DH5 $\alpha /$ pMBhis was grown on LB liquid medium suplemented with Ampicillin (100 mg/mL). Expression was conducted by inducing the transcription process with addition of various concentration of IPTG (isopropyl-D-thiogalactopyranose). We used several concentration of IPTG $(100 \mathrm{mM}-600 \mathrm{mM})$, and the cells were harvested 3 hours after induction with IPTG. The results of SDS-PAGE of the various expression with and without induction can be seen in Figure 6. Furthermore, SDS-PAGE of the supernatants and pellets after various centrifugation can be seen in Figure 7. The expression of pab was confirmed using western Blot against recAg38 from $M$ tuberculosis H37Rv (data not shown). 


\section{Purification of recAg38M}

Loss of protein during purification was minimized by inclusion of a histidine tag at $\mathrm{N}$-terminus, allowing purification using a Ni-matrix to capture histidine tag. The band of the protein recAg38M did not appear in the flowthrough (Figure 8 lane 2) as well as during wash steps (Figure 8 lanes 3 and 4 ), in contrast, the bands that coressponded to recAg38M were found during elution steps (Figure 8 lanes 5-7). However, there were still many other protein that were copurified so further washing may be warranted.

\section{Growth of E.coli DH5a/pMB38}

It was found that E.coli $\mathrm{DH} 5 \alpha / \mathrm{pMB} 38$ exhibited growth with slightly longer generation time (tD> 2 hours) compared to the host $(\mathrm{tD}=1.5$ hours) (Figure 9 ).

\section{DISCUSSION}

The present study aimed to express $p a b$ gene from a local strain of M. tuberculosis in heterologous system (E.coli) to achieve high antigen yields at potentially low cost. The construct was designed by omitting the putative signal peptide, so that the recombinant protein remained in the cytoplasm. Alignment of the amplified PCR product of $p a b$ gene isolated from malang showed 98\% homology with sequence of pab gene from $M$. tuberculosisH37Rv. Hence, it was expected that the recombinant protein recAg38M from Malang could have a similar immunological properties to recAg38 synthesized from $M$. tuberculosis $\mathrm{H} 37 \mathrm{Rv}$ when they are in the future used as serodiagnostic agent. However, we did not conduct immunological experiment yet. ${ }^{5}$

The $p a b$ gene from Malang was successfully expressed in E.coli $\mathrm{DH} 5 \alpha$, as the band did not present without IPTG induction. Therefore, the band that appeared after induction with IPTG must be the recAg38M protein. These was also confirmed using anti Ag38 (data was not shown). Nevertheless the amount of protein recAg38M was less than protein recAg38 originated from $M$. tuberculosis $\mathrm{H} 37 \mathrm{Rv}$, where Ag38 may account for $10 \%$ of the total protein.

The recombinant protein was dominated by the insoluble form, and only $25 \%$ of the protein was found in a soluble form. The failure to obtain recAg38M in a soluble form was the consequence of the fact that the expression of $p a b$ always lead to the formation of inclusion bodies that contain the insoluble form of the recombinant protein. ${ }^{2,5}$ It might be worthwhile to try coexpression of $p a b$ with fusion partners that are known to aid in increasing the solubility such as maltose-binding protein MalE. ${ }^{10}$
During the course of the expression experiment, the plasmid containing host showed a different behavior. The low rate of transformation of pMBhis into E.coli DH5 $\alpha$ suggested that a large amount of the recAg38M within the cell somehow disturb the homeostasis of host cell, so that the growth of E.coli DH5 $\alpha /$ pMBhis in the liquid medium was slightly slower than E.coli DH5a alone with a generation time of 2 hours compared to 1 hour (figure 9). Previous study has noted that the expression of recombinant protein retarded the growth of the host, such as in the case of expression of cymH gene of Klebsiella oxytoca in E.coli DH5 $\alpha .{ }^{11}$

During the course of expression experiment, the pMBhis containing host has shown a different behaviour from the wild type. Comparison of growth curve of wild type E.coli DH5 $\alpha$ and E.coli DH5 $\alpha /$ pMBhis can be seen in Figure 9.

Subcellular localization showed that recAg38M was partly located in the cytoplasm as the band corresponding to $37 \mathrm{kDa}$ that was found in supernatant (S100) after centrifugation at $100.000 \mathrm{xg}$ (figure 7 lane 8 ) was faint, whereas most of protein was found in the precipitate (P100) (figure 7 lane 9). The question whether recAg38 is only temporarily attached to periplasmic membrane or becomes a trans-membrane protein is still open. Attempts to release the protein from the membrane using Triton X-100 failed (data not shown). This finding was in contrasts with the recAg38 from M. tuberculosis H37Rv, which was found $90 \%$ in the cytoplasm. ${ }^{2}$

One crusial problem in producing recombinant protein is during purification process. To obtain pure protein, several purification steps are needed, so that at the end of the process the yield is low, and the proteins loss part of their immunogenicity. Hence there is a need to conduct a short and efficient purification process so that most of the protein could be purified with a high immunogenicity. This might be mediated through protein fusion with Histidin tag at the $\mathrm{N}$-terminus that was purified through Ni-NTA matrix. During the course of purification, the Ni-NTA matrix was used to capture the Histidine tag to increase the protein resolution accordingly. The purification of recAg38M using NiNTA affinity batch system showed that there were still contaminations of several proteins. Therefore, it is sugessted to repeat the purification procedure with optimizations such as changing the buffer that could increase the purity of recombinant protein.

In conclusion, pab gene of M. tuberculosis isolated from TB patient could be expressed in heterologous system in E.coli DH5a. Although the pab gene in our study genetically showed high homology to $p a b$ gene from $M$. tuberculosis $\mathrm{H} 37 \mathrm{Rv}$, further study was required to purify the protein, and to identify its biological function. 


\section{Acknowledgments}

Many thanks were given to Asnah Hidayati, Faizah and Khairuni for their excellent work in the expression of $p a b$ gene. We thank to Dr. Rintis Noviyanti from Eijkman Institute for providing the plasmid pPRoExHTc. We were grateful to Prof. Patricia Price from Western University for valuable comments. This study was financed by STRANAS grant from Indonesian government.

\section{REFERENCES}

1. Chang Z, Choudary A, Lathigra R, Quiocho FA. The immunodominant $38-\mathrm{kDa}$ lipoprotein antigen of $\mathrm{Myco}-$ bacterium tuberculosis is a Phosphate-binding protein. J Biol Chem. 1994;269;1956-68.

2. Wilkilson RJ, Haslov K, Rappuoli R, Giovannoni F, Narayanan PR, Desai CR, et al. Evaluation of the recombinant 38-kilodalton antigen of Mycobacterium tuberculosis as a potential immunodiagnostic reagent. J Clin Microbiol. 1997;35:553-7.

3. Cheng VCC, Yew WW, Yuen KY. Molecular diagnostics in tuberculosis. Eur J Clin Microbiol Infect Dis. 2005; 24:711-20.
4. Van der Zanden AGM. Spoligotyping, a tool in epidemiology, diagnosis and control of tuberculosis. Wageningen: Ponsen \& Looijen BV; 2002.

5. Singh M, Andersen AB, McCarthy JEG, Rohde M, Schutte $\mathrm{H}$, Sanders E, et al. The Mycobacterium tuberculosis 38-kD antigen: overproduction in Escherichia coli, purification and characterization. Gene. 1992;117:53-60.

6. Sambrook J, Fritsch E F,Maniatis T. Molecular cloning: a laboratory manual. New York: Cold Spring Harbour; 2001.

7. Ausubel FM, Brent R, Kingston RE, Moore DD, Seidmann JG, Sminth JA, et al. Current protocol in molecular biology. New York: Wiley and Sons; 1997.

8. Young DB, Garbe TR. Heat shock protein and antigen of Mycobacterium tuberculosis. J Infec Immun. 2001;59: 3086-93.

9. Yasukawa C, Kanei-Ishii T, Maekawa J, Fujimoto T, Yamamoto, Ishii S. Increase of solubility of foreign protein in $E$. coli by overproduction of bacterial thioredoxin. J Biol Chem. 1995;270:25328-31.

10. Gubernator B, Seidler A, Rögner M, Szczepaniak A. Overexpression and reconstitution of a Rieske iron-sulfur protein from the higher plant. Protein Expr Purif. 2003;29:8-14.

11. Mardining Raras TY. Study on the cyclodextrine metabolism in Klebsiella oxytoca M5a1. A molecular Approach. Saarbrucken: Dr Mueller Publisher; 2010. 